\title{
AFIRMACIJA RUSKE FEDERACIJE KAO VELIKE SILE
}

\author{
Zoran M. Karavidić \\ Univerzitet odbrane u Beogradu, Vojna akademija \\ Mitar P. Kovač*
}

Savremeno geopolitičko okruženje je poligon gde velike sile pokušaSvaju da uspostave i održe svoj status radi sveopšteg napretka države. Upravo u takvom okruženju kroz najviša strategijska akta moguće je pratiti razvoj statusa velikih sila. Promene njihovog uticaja u regionalnom i globalnom okruženju je stalni dinamički proces koji neposredno i posredno utiče na ostatak sveta. U radu će hronološki biti sagledana afirmacija Ruske Federacije, kao velike sile krajem XX i početkom XXI veka, i implikacije na okruženje.

Ključne reči: Ruska Federacija, velika sila, strategija nacionalne bezbednosti, vojna doktrina

\section{Uvod}

Dokazatelj koji treba da se ispolji da bi se jedna država proglasila velikom silom teško se može precizno definisati. U suštini, to je zbir različitih moći koje dovode do uticaja u međunarodnim odnosima, kako ekonomskih i vojnih, tako i političkih i drugih. Ekonomska snaga često se prepoznaje kao osnovni pokretački i najbitniji faktor moći države. Međutim, nije uvek tako. Nemačka je u drugoj polovini XX veka bila ekonomski džin, ali politički patuljak. To ie naiuočliiviie na statusu neposedovania statusa stalne članice Saveta bezbednosti. ${ }^{1}$ Suprotan primer je Kina, koja dugo posle Drugog svetskog rata nije bila ekonomski jaka, ali joj je status priznavan zbog velikog ljudskog potencijala. Sličan ljudski potencijal ima i Indija, ali je njen politički uticaj mnogo manji, sličniji Nemačkoj. Veličina teritorije države i prirodna bogatstva su od izuzetnog značaja. Takođe, nezaobilazan aspekt velike sile je i vojna moć, a u okviru nje i posedovanje nuklearnog oružja. Međutim, suštinski veliku silu čini uticaj u međunarodnim odnosima koji se javlja kao posledica svega navedenog i još mnogobrojnih faktora.

Ispoljavanje uticaja i moći u međunarodnoj zajednici uvek se kompleksno izražava. $\mathrm{Na}$ sceni je završetak ere unipolarizma sa jednom supersilom u međunarodnim odnosima - Sjedinjenim Američkim Državama (SAD). Multipolarizam polako preuzima presto značaja u međunarodnim odnosima. Pored SAD, kao svetski centri moći prikazuju se

\footnotetext{
* prof. dr. Mitar P Kovač je general-major u penziji

${ }^{1}$ Todorović, M., Đorđević, S., Multipolarna struktura međunarodnih odnosa na početku HHI veka, Vojno delo, Medija centar ,,Odbrana”, 4/2015, Beograd, 2015, str. 46.
} 
Ruska Federacija (RF), Narodna Republika Kina, a blizu su i mnoge druge države, što zbog svoje ekonomske, vojne, demografske ili druge snage.

Jedan od načina da se prati mesto i uloga države u globalnom okruženju je proučavanje Strategije nacionalne bezbednosti (SNB) i reagovanja države na svetska dešavanja. Strategija nacionalne bezbednosti u osnovnim crtama usmerava sistem odbrane, diplomatiju, privredu, nauku i mnoge druge delatnosti. Strategije zavise od mnogih faktora, koje državni organi pokušavaju što detaljnije da uoče i izraze, kako bi svoje mesto u svetu postavili na realnim i održivim osnovama. Zbog toga će i ponašanje Rusije biti praćeno kroz prizmu odrednica SNB, koje daju usmerenje delovanju i reflektuju dostignuti nivo sistema nacionalne bezbednosti RF.

Rad govori o mestu Ruske Federacije u globalnom okruženju, prevashodno u XXI veku. Uspon RF u međunarodnom okruženju je proces koji je započeo raspadom SSSR-a i proglašenjem RF kao nezavisne države, nakon čega je prošla kroz različite faze razvoja, da bi danas predstavila veliku silu u međunarodnim odnosima. U radu će biti navedeni nacionalni prioriteti u različitim periodima i sagledano njihovo stanje u okviru regionalnog i globalnog okruženja RF, što se hronološki može pratiti kroz vreme objavljivanja određene SNB kao najbitnijeg strategijskog dokumenta. Takođe, biće reči i o vremenu i uzrocima zbog kojih je određena SNB objavljena. Poređenje sa prethodnim i budućim strategijama je nezaobilazan aspekt shvatanja državne politike, pa će tako, kroz različite SNB i njihove implikacije, biti uočen i razvoj i afirmacija RF, posebno u poslednjim godinama.

\section{Mesto i značaj strategije nacionalne bezbednosti u Ruskoj Federaciji krajem 20. i početkom 21. veka}

Poslednju deceniju XX veka karakterisali su značajni integracioni i dezintegracioni procesi u međunarodnim odnosima, čiji domašaj ni danas nije lako predvideti. Ujedinjenje Nemačke, raspad SSSR-a i Varšavskog ugovora smatrani su krajem tzv. hladnog rata i stupanja na scenu novog svetskog poretka. Na red su došle drugačije vrste sukoba, čiji su uzroci dugi niz godina bili potiskivani višim značajem koje su nametale supersile hladnog rata. Pomenuti sukobi se težišno vode na određenim lokalnim i regionalnim nivoima i vrlo su retko posledica određenih međudržavnih sukoba. To su ratovi za identitet, kao i zbog istorijskih nepravdi, mitova i legendi. U takvom okruženju svoje mesto osmišljavaju i oblikuju i velike i jake države koje nove opasnosti tumače kroz različite prizme, a sve radi održavanja i unapređenja svog statusa u globalnom okruženju.

Svojom kompleksnošću SNB pokušavaju da odgovore na sve moguće izazove, rizike i pretnje koji se stavljaju pred sistem nacionalne bezbednosti. Kada se govori o SNB velikih sila, sve opasnosti koje se uzimaju u razmatranje svakako su vezane za globalne okvire i mesto i ulogu te sile u svetskom okruženju. Kroz svoje definisanje mesta i uloge velike sile definišu i odnos ka svim okolnim i ostalim državama, određuju prioritete svojih odbrambenih interesa i načine reakcije na bilo kakvo ugrožavanje. Na taj način sve SNB velikih sila utiču u svetskim okvirima i stavljaju do znanja ostalim državama i narodima gde je njihovo mesto u svetskim tokovima. U radu će, s tim u vezi, biti dotaknut i odnos 
RF ka svom okruženju i prostorima koje smatraju za zonu uticaja, jer je to realan način sagledavanja načina na koji se strategija sila manifestuje u praksi.

Zaostavštine prošlosti i pokušaji država da im se prilagode i nađu svoje mesto u svetu nametnuli su potrebu za redefinisanjem SNB, koje su svoj najdinamičniji oblik ispoljile baš u XXI veku. Za razliku od zapadnih zemalja, u periodu posle Drugog svetskog rata SSSR je strategiju podređivao doktrini, te je Ratna (vojna) doktrina bio najviši strategijski dokument. Ona je bila i politički dokument kojim se službeno izražavala vojna politika Komunističke partije Sovjetskog Saveza. Ovakav pogled na vojnu doktrinu preuzela je i posthladnoratovska RF. Međutim, od 1997. godine RF je preuzela zapadni tip hijerarhije i za najviši akt postavila Koncept nacionalne bezbednosti koji je u potpunosti imao značaj i formu Strateqiie nacionalne bezbednosti iz koje su proistekle odgovarajuće voine doktrine. ${ }^{2}$ Prva zvanična SNB RF, objavljena pod tim nazivom, pojavila se ,,tek” 2009. godine. Nove vojne doktrine RF nemaju oblik hladnoratovskih doktrina SSSR-a već su mnogo sličnije nacionalnim vojnim strategijama SAD i gotovo u potpunosti se mogu razmatrati u istom kontekstu. Razmatranje SNB RF biće neodvojivo od razmatranja najbitnijih istorijskih događaja koji su ih oblikovali i usmerili (tabela 1).

Tabela 1 - Uporedni pregled strategijskih dokumenata RF sa istorijskim dešavanjima

\begin{tabular}{|c|c|c|c|c|}
\hline Vreme & $\begin{array}{l}\text { Strategijski dokumenti } \\
\text { RF }\end{array}$ & Dešavanja u RF & $\begin{array}{l}\text { Dešavanja u } \\
\text { okruženju RF }\end{array}$ & $\begin{array}{l}\text { Dešavanja u } \\
\text { svetu }\end{array}$ \\
\hline 1988. & & & $\begin{array}{l}\text { - Rat za Nagorno- } \\
\text { Karabah (1988-94) }\end{array}$ & \\
\hline 1991. & & - Formiranje ZND & $\begin{array}{l}\text { - Rat za } \\
\text { Pridnestrovlje } \\
\text { (1991-92) } \\
\text { - Rat u Južnoj Osetiji } \\
\text { (1991-92) }\end{array}$ & \\
\hline 1992. & & $\begin{array}{l}\text { - Sukob u oblasti } \\
\text { Prigorodno } \\
\text { (Osetijsko-ingušetski } \\
\text { konflikt) }\end{array}$ & $\begin{array}{l}\text { - Rat u Abhaziji } \\
\text { (1992-93) } \\
\text { - Sukob u } \\
\text { Tadžikistanu } \\
\text { (1992-97) }\end{array}$ & \\
\hline 1993. & Vojna doktrina RF & $\begin{array}{l}\text { - Ruska konstitutivna } \\
\text { kriza }\end{array}$ & & \\
\hline 1994. & & $\begin{array}{l}\text { - Prvi čečenski rat } \\
\text { (1994-96) }\end{array}$ & & $\begin{array}{l}\text { - SAD „,SNB } \\
\text { angažovanja i } \\
\text { širenja" }\end{array}$ \\
\hline 1997. & $\begin{array}{l}\text { Koncepcija } \\
\text { nacionalne } \\
\text { bezbednosti RF }\end{array}$ & $\begin{array}{l}\text { - Stvaranje unije RF i } \\
\text { Belorusije }\end{array}$ & \multicolumn{2}{|c|}{ - Formiranje GUAM grupe } \\
\hline 1998. & & $\begin{array}{l}\text { - Velika avgustovska } \\
\text { finansijska kriza }\end{array}$ & & \\
\hline
\end{tabular}

\footnotetext{
${ }^{2}$ Mirković, T., Strategije i ratne doktrine supersila i blokova, Medija centar „Odbrana”, Beograd, 2003, str. 18-19.
} 
Međunarodno okruženje

\begin{tabular}{|c|c|c|c|c|}
\hline Vreme & $\begin{array}{c}\text { Strategijski dokumenti } \\
\text { RF }\end{array}$ & Dešavanja u RF & $\begin{array}{l}\text { Dešavanja u } \\
\text { okruženju RF }\end{array}$ & $\begin{array}{l}\text { Dešavanja u } \\
\text { svetu }\end{array}$ \\
\hline 1999. & & $\begin{array}{l}\text { - Drugi čečenski rat } \\
(1999-09)\end{array}$ & & $\begin{array}{l}\text { - NATO } \\
\text { intervencija } \\
\text { protiv SRJ } \\
\text { - Usvajanje } \\
\text { novog } \\
\text { koncepta } \\
\text { NATO }\end{array}$ \\
\hline 2000 & $\begin{array}{l}\text { Koncepcija } \\
\text { nacionalne } \\
\text { bezbednosti RF } \\
\text { - Vojna doktrina RF }\end{array}$ & & & \\
\hline 2001. & & $\begin{array}{l}\text { - Formiranje } \\
\text { Šangajske } \\
\text { organizacije }\end{array}$ & & \\
\hline 2002. & & - Formiranje ODKB & & \\
\hline 2008. & & $\begin{array}{l}\text { - Rusko-gruzijski rat } \\
\text { - Rusko priznanje } \\
\text { Južne Osetije i } \\
\text { Abhazije } \\
\text { - Formiranje BRIK } \\
\text { (kasnije BRIKS) }\end{array}$ & & $\begin{array}{l}\text { - Postavljanje } \\
\text { dela protiv- } \\
\text { balističkog } \\
\text { štita SAD u } \\
\text { Poljskoj }\end{array}$ \\
\hline 2009. & $\begin{array}{l}\text { Strategija nacionalne } \\
\text { bezbednosti RF do } \\
2020 \text {. godine }\end{array}$ & & & \\
\hline 2010. & Vojna doktrina RF & & $\begin{array}{l}\text { - Etnički sukobi u } \\
\text { Kirgistanu } \\
\text { - Sukobi u } \\
\text { Tadžikistanu } \\
\text { (2010-12) } \\
\end{array}$ & \\
\hline 2014 & Vojna doktrina RF & - Aneksija Krima & $\begin{array}{l}\text { - Nasilna smena } \\
\text { vlasti u Ukrajini } \\
\text { - Rat u Istočnoj } \\
\text { Ukrajini (2014-) }\end{array}$ & \\
\hline 2015. & $\begin{array}{l}\text { Strategija nacionalne } \\
\text { bezbednosti RF }\end{array}$ & $\begin{array}{l}\text { - Formiranje } \\
\text { Evroazijskog } \\
\text { ekonomskog saveza }\end{array}$ & & \\
\hline
\end{tabular}

Sagledavajući istorijski razvoj mogu se uočiti tri osnovne faze u razvoju i afirmaciji RF kao velike sile:

1) Faza traženja mesta u novom geopolitičkom okruženju posle hladnog rata. Trajala je od raspada SSSR-a, pa do početka XXI veka i smene političkih garnitura.

2) Faza revitalizacije državnih i nacionalnih interesa - zaokret u politici RF, povratak nacionalnom identitetu, revitalizacija svih elemenata države i postavljanja stabilnih osnova. Faza je trajala do završetka rata RF sa Gruzijom 2008. godine i „objave” pomalo zaboravljene snage RF.

3) Faza daljeg napretka - predvidiv razvoj na stabilnim osnovama, dalji napredak države i potvrda visokog geopolitičkog mesta RF. 


\section{Traženje mesta Ruske Federacije u novom geopolitičkom okruženju posle hladnog rata}

Dolaskom Mihaila Gorbačova (na vlasti od 1984. do 1991. godine) promovisana je nova politika SSSR-a, koja je za krajnji cilj imala povlačenje vojske iz stranih država, težnju za pregovorima sa Zapadom i smanjenje konvencionalnog i nuklearnog oružja. Gorbačovljevo gledište je odbacivalo stav o neizbežnosti opšteg rata ${ }^{3}$. U tom smislu promovisano je i povlačenje jedinica Sovjetske armije sa teritorija istočnoevropskih zemalja. Krajnji proizvod tih procesa bio je raspad Varšavskog ugovora i SSSR-a.

Prvi Kongres narodnih poslanika Ruske Sovjetske Federativne Socijalističke Republike je 12. juna 1990. godine doneo deklaraciju o državnom suverenitetu Rusije. Kasnije, decembra 1991. godine, formirana je Zajednica nezavisnih država i ona označava raspad SSSR-a. ${ }^{4}$ Između NATO-a i Rusije uspostavljeni su specijalni odnosi. Sjedinjene Države postale su jedina globalna supersila. Daleko od ostalih po pitanju ekonomske i vojne moći, nametnuli su se kao globalni svetski lider. Najveći neprijatelj SAD u XX veku je savladan, a njegovo mesto zauzela je Ruska Federacija koja nije imala snagu saveza koji je nasledila, niti je imala volju i interes da nastavi suprotstavljanje.

Sistem međunarodnih institucija i odnosa, brižljivo izgrađivan u prošlosti, izgubio je pobedom jednog pola sopstvenu ravnotežu. Nestankom bipolarne strukture svetskih odnosa narušila se svetska ravnoteža snaga. Time je nestao presudan uslov delotvornosti normi međunarodnog prava i poštovanja međunarodnog morala. Verski, nacionalni, ekonomski, tehnološki, ekološki i drugi problemi, koji su do tada bili u drugom planu, dobili su na ubrzanju i važnosti. Planeta je još jednom u svojoj istoriji postala prostor nepredvidivih dešavanja i kretanja.

Sjedinjene Države i njihov hladnoratovski saveznik NATO osetili su potrebu i mogućnost da svoje prisustvo i uticaj šire izvan prostora koji je bio ograničen „gvozdenom zavesom”. NATO širi svoje „nadležnosti” na južnu zonu Mediterana i Bliski istok, s tendencijom daljeg širenja prema istoku. Radi toga SAD su promovisale koncept izgradnje „novog svetskog poretka". Taj cilj ozvaničen je u SNB administracije Bila Klintona (predsednik od 1993. do 2001. godine), koja je bila označena kao „Strategija nacionalne bezbednosti angažovanja i širenja". 5

U kratkom periodu posle 1991. godine izgledalo je da će američki trijumf dugo trajati, pošto nijedan rival nije bio na vidiku. Američki lideri su govorili da je XXI vek - vek Amerike i američke dominacije. Predsednici Bil Klinton i Džordž Buš samouvereno su to tvrdili. ${ }^{6}$ Međutim, Kina, Rusija i druge države, oslanjajući se na svoje društveno uređenje i

\footnotetext{
${ }^{3}$ Mirković, T., op. cit., str. 147.

${ }^{4}$ Zajednicu nezavisnih država čini jedanaest bivših sovjetskih republika: Jermenija, Azerbejdžan, Belorusija, Kazahstan, Kirgizstan, Moldavija, Rusija, Tadžikistan, Ukrajina i Uzbekistan. Turkmenistan je izašao iz članstva 26. avgusta 2005. godine, te je danas samo pridružena članica. Dve postsovjetske države su 1997. godine stvorile Uniju Rusije i Belorusije, koja je danas formalno konfederalne prirode, ali joj je cilj da u budućnosti preraste u federaciju (kao nekadašnji SSSR).

${ }^{5}$ National Security Strategy of Engagement and Enlargement, The President of the United States, 1994, dostupno na: http://history.defense.gov/Portals/70/Documents/nss/nss1994.pdf?ver=2014-06-25-121219-500.

${ }^{6}$ Bžežinski, Z.: Amerika-Kina i sudbina sveta, Albatros Plus, Beograd, 2013, str. 9.
} 
raspoložive resurse, demonstrirale su iznenađujuću sposobnost za ekonomski rast i tehnološku inovaciju. To će proizvesti novi strah u vezi sa SAD kao vodeće svetske sile tog perioda. Zbog toga se čine i očigledni napori da se Rusija politički, ekonomski i vojno oslabi i razjedini. To će posebno biti primećeno u kasnijim godinama, ali i prepoznato i apostrofirano u SNB RF.

U zemljama istočne Evrope pobeđuju antikomunističke i antisovjetske snage. One, veoma brzo nakon izlaska iz jednog, pristupaju drugom vojno-političkom savezu. Izlaze iz VU i skoro „preko noći” pristupaju NATO-u, verujući da će na taj način obezbediti svoje vitalne nacionalne interese.

Posle raspada SSSR-a Rusija se našla u ogromnim problemima. Započet je domino efekat dezintegracije i urušavanja državnog i nacionalnog integriteta RF. Rušenje geopolitičkih struktura SSSR-a prouzrokovalo je i rušenje osnova državnih struktura u samoj RF. Proces dezintegracije ispoljavao se kroz više istovremenih procesa: ekonomski krah i divlja privatizacija, ${ }^{7}$ teritorijalna dezintegracija (RF obuhvata $76 \%$ teritorije i oko $60 \%$ populacije bivšeg SSSR-a), separatizam, terorističke akcije usmerene protiv države i društva, organizovani kriminal, korupcija, demografsko opadanje, nesposobnost organa izvršne vlasti i političke elite. Pitanja bezbednosti RF usložavali su i međuetnički i građanski ratovi u drugim bivšim republikama SSSR-a. Ruski narod i druge manjine zatražili su pomoć i intervenciju u Gruziji (Južna Osetija, Abhazija), Moldaviji (Pridnjestrovlje), Azerbejdžanu (Nagorno-Karabah), te je RF na neki način morala učestvovati u prevazilaženju sukoba u blizini svojih granica.

Rusija ulazi u tranziciju koja će na nju ostaviti velike posledice čije će rešavanje trajati dugi niz godina. $U$ isto vreme, u sferi vojne sile, trebalo je ogromnu sovjetsku armiju svesti na pravu meru nove države. To se usložavalo sa sve većim separatističkim težnjama na jugu zemlje i otvorenim oružanim pobunama i terorizmom. U takvom okviru RF je izgrađivala svoju poziciju i pokušavala da zauzme što bolje mesto za predstojeća dešavanja.

Uprkos navedenim problemima, u razdoblju između 1991. i 1993. godine, RF je pokušala održati status svetske sile razvijanjem partnerstva sa SAD. Pokazalo se kako u mnogim slučajevima ruski interesi nisu kompatibilni s američkim. Američki planovi o budućnosti NATO-a i njegovom proširenju na istok Evrope ocenjeni su kao pokušaj izolovanja RF. Američko mešanje u odnose među državama na području ZND viđeno je kao pokušaj osporavanja vodeće uloge RF. Ali, zbog vlastite slabosti RF nije mogla uticati na navedene događaje u smeru njihove promene.

$U$ takvim geopolitičkim uslovima na početku 90 -ih godina $X X$ veka ruska vlast, na čelu sa Borisom Jeljcinom (predsednik RF od 1991. do 1999. godine), definisala je vojnu doktrinu na mnogim pogrešnim premisama, a delom i na starim shvatanjima. Vojna doktrina RF iz 1993. godine, bez obzira na to što je bila privremenog karaktera, nije se zasnivala na analizi geopolitičke situacije $^{8}$ u kojoj se RF nalazila tih godina. Nije sadržala precizno definisane ruske nacionalne interese, a oni su se mogli naslutiti sagledavanjem ostalih elemenata dokumenta. Doktrina je, pre svega, predstavljala težnju RF da izađe iz perioda konfrontacije sa Zapadom, tj. želju da sa vodećim zapadnim zemljama, po svaku cenu, razvije partnerstvo i saradnju.

\footnotetext{
${ }^{7}$ Perišić, S.: Nacionalna bezbednost kao jedan od osnovnih činilaca geopolitičkog pozicioniranja RF na početku HHI veka, Vojno delo, Medija centar ,,Odbrana”, zima/2010, Beograd, 2010, str. 105.

${ }^{8}$ Ibid., str. 104.
} 
Nepostojanje kvalitetno razrađenog političkog dokumenta koji bi odražavao sveukupnost stavova države o njenim ciljevima, a koji bi se zasnivao na analizi geopolitičke situacije, suštinski je doprineo da postavke Vojne doktrine iz 1993. godine budu, praktično, neupotrebljive. ${ }^{9}$ Neupotrebljivosti Vojne doktrine sve više je doprinosila i katastrofalna ekonomska situacija. Reformski procesi se nisu odvijali organizovano i u jedinstvenom cilju već često stihijski sa pokazateljima koji su ukazivali na opšte propadanje svih elemenata državne strukture.

Ovo iskustvo dovelo je do postupnog hlađenja prozapadne orijentacije RF. Počelo je okretanje prema definisanju nacionalnih interesa kao vodećih principa ruske spoljne politike i ponašanja na međunarodnoj političkoj sceni. Navedena promena mogla se primetiti usmeravanjem na ostvarivanje nacionalnih interesa, a ne više prvenstveno traženjem partnerstva sa Zapadom. Zaokret je vidljiv i u posvećivanju veće pažnje evroazijskom prostoru (strateško partnerstvo s Kinom, nastojanja za jačanjem ekonomskih veza s Japanom i Južnom Korejom, obnavljanje veza s Indijom i protivljenju ekspanziji NATO-a).

Koncepcija nacionalne bezbednosti RF, objavljena u decembru 1997. godine, bio je prvi politički dokument u novijoj istoriji RF koji je izražavao državne stavove o bezbednosti ruskog društva i države, a koji su dugo čekali i stručna javnost i sami građani. U dokumentu se sagledava mesto i uloga RF u sistemu međunarodnih odnosa i čini otklon od dotadašnje strukture najviših strateških dokumenata koji se izražavao kroz vojne doktrine. Kao refleksija užeg kruga ljudi oko Jeljcina, Rusija naglašava partnerstvo sa Zapadom i želju da bude deo zapadnog sistema, ali, sa druge strane, po prvi put prepoznaje ${ }^{10}$ i naglašava negativnost u pogledu širenja NATO-a na istok Evrope (u doktrini iz 1993. godine kao spoljna pretnja bilo je pomenuto širenje vojnih blokova). Širenje NATO-a ipak se prepoznaje kao jedan od najmanjih problema i predlaže se da se sve može rešiti uz pregovore sa Rusijom kao jedinom istinskom evroazijskom silom. Najveća pretnja Rusiji nije ništa spoljno već unutrašnji problemi, težišno ekonomske prirode i lokalni sukobi. Insistira se da Rusija u svetskom društvu ne bude samo posmatrač već jedan od odlučujućih segmenata u svim sferama budućem multipolarnog sveta. Navedene stavke mogu se tumačiti kao početak želje za afirmacijom Rusije kao velike svetske sile. Moraće da prođe skoro dve decenije da Rusija u tom smislu bude javno priznata od zapadnih zemalja.

Koncept nacionalne bezbednosti iz 1997. godine uvažava geopolitičke analize i donosi novinu u sistemu bezbednosti Rusije i, kao takav, značajan je napredak u određivanju mesta i uloge RF u novonastalom okruženju. lako je subjektivno prožet stavovima liberalnih struja koje značajno teže otvaranju Rusije ka Zapadu, svakako stvara podlogu za dalja razmatranja i realna sagledavanja položaja u kojem se nalazila Rusija, ali i mogućnost prilagođavanja na buduće oblike ugrožavanja koji će se ubrzo javiti.

Ovaj period je vreme prelaza sa shvatanja nacionalne bezbednosti po SSSR modelu na moderne koncepcije, kojima RF definiše svoje prioritete i pokušava da popravi opšte loše društveno i ekonomsko stanje. Istovremeno, ovaj period je period lutanja u spoljnoj politici RF koja traži svoje saveznike i pokušava pred kraj veka da učvrsti svoje mesto u okruženju, a istovremeno se stabilizuje bezbednosno i ekonomski. Po usvojenoj Koncepciji nacionalne bezbednosti možemo zaključiti da Rusija realno ceni svoje mesto i mogućnosti i nastoji da taj status popravi.

\footnotetext{
${ }^{9}$ Ibid., str. 106.

${ }^{10}$ lbid., str. 107.
} 


\section{Revitalizacija državnih i nacionalnih interesa početkom 21. veka}

Na kraju XX i početkom XXI veka dolazi do značajnih događaja na svetskoj i unutrašnjoj sceni koji utiču na dalje ruske strateške korake. Najvidljiviji su bili:

- velika ruska avgustovska finansijska kriza 1998. godine. Nastala je pod uticajem vladajućih elita koje su RF previše izložile zapadnom tržištu i učinili je zavisnu od finansijske pomoći, pri čemu se socijalno stanje nije popravilo;

- NATO intervencija protiv SRJ. Rusko rukovodstvo je do tada prećutno prihvatalo širenje NATO-a, što zbog nemogućnosti da adekvatno reaguje zbog opšte loše situacije u državi, što zbog verovanja da će NATO borbene misije (koje se ne odnose na odbranu svojih članica) sprovoditi kroz SB UN gde RF ima pravo veta. To je bilo praktično širenje misija koje NATO sprovodi. Novi koncept zaštite ljudskih prava koji je NATO primenio na Kosovu i Metohiji mogao se primeniti i negde blizu ili u Rusiji;

- formiranje GUAM grupe pod patronatom $S A D^{11}$, a direktno protiv interesa RF;

- početak Drugog čečenskog rata (od 1999. do 2009. godine);

- usvajanje novog doktrinarnog koncepta NATO-a 1999. (april 1999. godine - u jeku napada na SRJ) gde se, govoreći o odgovornosti NATO-a, uvodi termin evroatlantska zona, u koju je uključena „zona Mediterana”, sa Bliskim i Srednjim istokom, kao i deo centralne Azije.

Sva ta dešavanja dovode RF u položaj da shvata da više nije partner ili da nikada nije ni bila partner Zapadu. Razvija se ideja da je NATO postao previše agresivan i još u proleće 1999. godine počinje da se razmatra promena dotadašnje Koncepcije nacionalne bezbednosti iz 1997. godine i Vojne doktrine iz 1993. godine.

Dolazak Vladimira Putina (predsednik RF 2000-2008. i od 2012. godine) donosi zaokret u politici RF. Tako je već početkom 2000. godine Koncepcija nacionalne bezbednosti iz 1997. godine dopunjena i korigovana, ${ }^{12}$ a već u aprilu iste godine utvrđena je nova Vojna doktrina RF. ${ }^{13}$ Koncepcija je definisala najvažnije pravce državne politike RF:

- prepoznaje se da postoji namera nekih država da uruše snagu Rusije (provlači se kroz sve kasnije SNB);

- povećava se bitnost uticaja spoljnih pretnji za razliku od 1997. godine;

- zadržava se stav o teškoj ekonomskoj situaciji i potrebi za ekonomskim boljitkom.

Po prvi put se jasno ističe da RF, kao evroazijska država, ima svoje interese u Evropi, na Bliskom istoku, u Zakavkazju, centralnoj Aziji i azijsko-tihookeanskom regionu. Ugrožavanje ruskih interesa u tim regionima smatra se ugrožavanjem njene nacionalne bezbednosti. Pored toga, jasno je naznačeno da ugrožavanje nacionalne bezbednosti Rusije na međunarodnom planu predstavlja, pored ostalog, i širenje NATO-a na istok. ${ }^{14}$

\footnotetext{
${ }^{11}$ Konstantan uticaj SAD na blisko okruženje RF manifestovao se i formiranjem regionalne organizacije GUAM grupe (Gruzija, Ukrajina, Azerbejdžan i Moldavija) oktobra 1997. godine. Uzbekistan, koji je 1999. godine istupio iz ODKB, iste godine priključio se GUAM-u, odakle se povukao 2005. godine.

${ }^{12}$ Koncepciя nacionalınoŭ bezopasnosti Rossiǔskoŭ Federacii, Prezident Rossii, objavljena 1997, dopunjena 2000, dostupno na: http://www.mid.ru/foreign_policy/official_documents/-lasset_publisher/CPtlCkB6BZ29/content/id/589768.

${ }^{13}$ Voennaя doktrina Rossiǔskoŭ federacii, Prezident Rossii, 2000, http://www.ng.ru/politics/2000-04-22/5_doktrina.html.

${ }^{14}$ Perišić, S., op. cit.,str. 108.
} 
Primena Koncepcije nacionalne bezbednosti, utemeljene na geopolitičkim analizama, u velikoj meri je doprinelo da RF, u nastupu u međunarodnim odnosima, u zaštiti nacionalnih interesa i u definisanju energetske politike, zauzme jasnu i predvidivu politiku, oslobođenu neodređenosti i „slabog dometa”. ${ }^{15}$ Upravo, konstantna analiza geopolitičke pozicije RF, koju vrše najviše državne vlasti, uticala je da se politika nacionalne bezbednosti stalno preispituje i dopunjuje. Ovim strategijskim dokumentima stvorene su pretpostavke za pouzdano sprečavanje unutrašnjih i spoljnih pretnji nacionalnoj bezbednosti, za dinamičan razvoj i transformisanje RF u jednu od vodećih svetskih država.

Karakteristika ovog perioda jesu planske aktivnosti koje vode ka rešavanju pojedinačnih problema težišno u državi, a zatim i u regionu. Završavaju se veći sukobi u Čečeniji i počinje formiranje bitnijih regionalnih organizacija. Shvatajući značaj bezbednosti u Evropi, ali i da bi na neki način smanjila opasnost od širenja NATO-a, Rusija je 2009. godine predstavila Predlog sporazuma o Evropskoj bezbednosti, koji pod pritiskom SAD ne nailazi na odobravanje u evropskim državama. ${ }^{16}$

Konkretni koraci na ujedinjavanju napora centralnoazijskog prostora i onemogućavanju ekspanzije drugih svetskih centara moći učinjen je formiranjem Šangajske organizacije. ${ }^{17}$ Pored toga, predsednici RF i Kine su, početkom juna 2011. godine, potpisali Deklaraciju $^{18}$ kojom su se obavezali da će se međusobno podržati u slučaju ugrožavanja bezbednosti. Kina je, kao i RF, istovremeno i članica Organizacije pet zemalja u usponu - BRIKS (eng: Brazil, Russia, India, China, South Africa - BRICS) koje karakteriše brži ekonomski razvoj od drugih. Pogodan položaj i prirodni potencijal obezbeđuje im sirovinsku bazu za njihov ekonomski razvoj.

$U$ pogledu regionalne bezbednosti RF održava različite vojno-političke odnose sa susednim zemljama. U tom pogledu najznačajnija je, svakako, Organizacija Ugovora o kolektivnoj bezbednosti - ODKB ${ }^{19}$ (rus: Организация Договора о коллективной безопасности), nastala na prostoru bivšeg SSSR-a, koja se zasniva na bezbednosno-vojnoj saradnji. ODKB od nastanka pa do današnjeg dana (što je vidno i u SNB RF iz 2015. godine) teži da se pretvori u univerzalnu međunarodnu organizaciju, koja će biti u stanju da se suprotstavi regionalnim izazovima i vojno-političkim i vojnostrategijskim pretnjama.

\footnotetext{
${ }^{15}$ Ibidem., str. 112.

${ }^{16}$ Lišanin, M., Cupać, B.: Rusija, NATO, EU: Komplementarni ili konkurentski pogledi na novu bezbednosnu arhitekturu Evrope, Vojno delo, Medija centar „Odbrana”, proleće/2013, Beograd, 2013, str. 112.

17 Šangajska organizacija osnovana je 2001. godine, a čine je: Kina, RF, Kazahstan, Tadžikstan, Kirgizija i Uzbegistan. Organizacija nema ulogu vojnog bloka, a njeni glavni zadaci su: obezbeđenje stabilnosti i bezbednosti ujedinjenih zemalja; borba protiv terorizma, separatizma, ekstremizma i trgovine narkoticima i ljudima; razvoj ekonomske saradnje, energetskog partnerstva i naučne i kulturne razmene.

${ }^{18}$ Sakan, M.: Geopolitika NR Kine, Vojno delo, Medija centar „,Odbrana”, jesen/2013, Beograd, 2013, str. 33.

${ }^{19}$ Organizaciju Ugovora o kolektivnoj bezbednosti osnovale su: Ruska Federacja, Belorusija, Jermenija, Kazahstan, Kirgistan i Tadžikistan. Osnivački akt potpisan je 7. oktobra 2002. godine. Zemlje koje su okupljene u ovaj vojno-politički savez imaju cilj zajedničke odbrane i pružanja vojne pomoći u slučaju agresije na neku od članica. Status posmatrača u ovoj organizaciji 2013. godine dobili su Srbija i Avganistan. Predviđeno je da ukoliko neka država ili grupa država izvrši agresiju na jednu od država potpisnica, to će se tretirati kao agresija protiv svih država potpisnica i sve ostale države potpisnice će joj pružiti vojnu i svaku drugu neophodnu pomoć koristeći sva raspoloživa sredstva, u smislu ostvarivanja prava na kolektivnu odbranu, a u skladu sa članom 51. Ustava UN.
} 
Očigledno, RF podržava konsenzus, saradnju sa Zapadom, ali ne po cenu dominacije SAD u njenom ,,dvorištu”, Rusija postavlja ,,crvene linije” za svoj teritorijalni integritet i suverenitet države, ali i uticaj u svom okruženju. Rusija se rasterećuje unutrašnjih problema, ispoljava veliki uticaj na regionalno okruženje i konačno, deset godina posle hladnog rata, spremna je da se ponovo uključi u trku za najviša mesta na svetskoj sceni.

\section{Nove okolnosti u prvoj deceniji 21. veka i najznačajniji događaji za Rusku Federaciju}

lako je dopunjena Koncepcija nacionalne bezbednosti iz 2000. godine davala čitavu deceniju usmerenje RF u ostvarivanju ciljeva nacionalne bezbednosti i postavljanju u geopolitički okvir, različiti politički uticaji i dešavanja su zahtevala stalno preispitivanje i prilagođavanje novonastalim situacijama. Najznačajniji događaji i zbivanja koji su uticali na promenu Koncepta nacionalne bezbednosti su:

- unutrašnje bezbednosne pretnje koje su se ogledale u terorističkim pretnjama; ${ }^{20}$

- Rusko-gruzijski rat od 7. do 16. avgusta 2008. godine;

- izgradnja i širenje sistema protivbalističke zaštite od strane SAD;

- potrebe da se precizira dalji ekonomski razvoj i iskoriste ogromni prirodni resursi.

$\mathrm{Na}$ većinu pomenutih događaja poseban uticaj imale su SAD svojom politikom. Upletenost u unutrašnje stvari u RF i njenom okruženju dolazila je do izražaja više puta. Nastojanje SAD da se geopolitički utvrde u Gruziji reflektovalo se kroz pomoć koju su SAD dale Gruziji u vrednosti od tri milijarde dolara nakon 1991. i jednu milijardu dolara posle rata 2008. godine, pružajući joj stalnu podršku. ${ }^{21}$

Rusija se uvek kotirala visoko u geopolitičkom pogledu, pretežno zbog njenih bogatih nalazišta nafte i gasa i kontinuiranog statusa nuklearne supersile. Međutim, njen vojni potencijal, krajem XX i početkom XXI veka, bio je razvodnjen njenim ekonomskim, političkim i demografskim problemima. Po nekim zapadnim analitičarima, da Rusija nema nuklearno oružje i da neke evropske zemlje nisu zavisne od njihove nafte i gasa, ona ne bi zauzimala visoko mesto na piramidi globalne geopolitičke moći. ${ }^{22}$ Zbog toga izgradnju sistema protivbalističke zaštite u Evropi, RF shvata kao težnju SAD da naruši nuklearni balans i postigne dominaciju u tom ključnom vojnom segmentu. Suštinski se teško može govoriti o strategijama velikih sila, a da se pri tom ne uključi u razmatranje uticaj nuklearnog oružja. Svojim karakteristikama ono u velikoj meri definiše politiku države koja ga poseduje i stavlja je na mesto globalnog igrača na svetskoj sceni. Iz navedenog se može zaključiti da država koja ima mogućnost da zaokruži ovaj tehnološki proces izgradnje i upotrebe nuklearnog oružja sama po sebi poseduje ogromne kapacitete, što je svakako pozicionira globalno. Poredak u kojem je omogućeno sigurno uzajamno uništenje velikih sila učinilo je da se svrha nukle-

\footnotetext{
${ }^{20}$ U toku Drugog čečenskog rata (1999-2009) izvršen je veliki broj pokušaja terorističkih napada u Rusiji, od kojih su mnogi i uspeli. Poznati su bili napadi terorističkih grupa u pozorištu u Moskvi - oktobar 2002. godine i u školi u Severnoj Osetiji - septembra 2004. godine. Zbog toga se dugi niz godina izvodila protivteroristička borba u Čečeniji, čiji je kraj objavljen 2009. godine;

${ }^{21}$ Bžežinski, Z., op. cit., str. 95.

${ }^{22}$ Bžežinski, Z., op. cit., str. 29.
} 
arnog oružja svede na odvraćanje protivnika od napada, čime je ova vrsta naoružanja paradoksalno stekla izrazito defanzivni karakter. Na drugoj strani, antibalistički štit, ukoliko bi bio usavršen do nivoa gde može da obezbedi neranjivost sili koja ga poseduje, dobio bi izrazito ofanzivno obeležje, jer bi omogućio njegovom posedniku da preti upotrebom svojih bojevih glava na ofanzivan način bez straha od odmazde. U tom smislu RF vidi kao pretnju najvišeg nivoa izgradnju protivbalističkog štita od strane SAD, jer bi se na taj način postigla strategijska prednost u eventualnom nuklearnom konfliktu.

Svetske potrebe za fosilnim gorivima rastu i pored razvoja alternativnih snabdevanja energijom. Rast potreba u narednim decenijama višestruko će porasti, pri čemu će biti očigledan u azijskim brzorastućim ekonomijama. ${ }^{23}$ Rusija u tom segmentu u potpunosti nalazi svoje mesto, postavljajući se kao značajan snabdevač resursa i tu svoju prednost u potpunosti održava (slika 1). To će biti zamajac obnove ruske ekonomske snage posle godina propadanja i stagnacije.

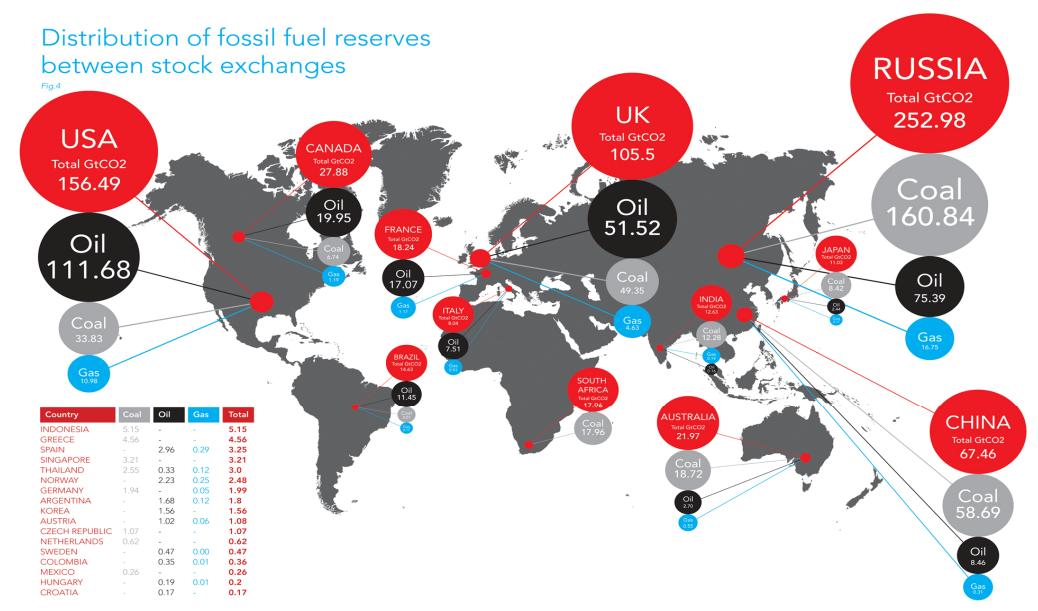

Slika 1 - Distribucija fosilnih goriva između berzi 2013. godine (u milijardama tona CO2) ${ }^{24}$

Pored navedenog ogromnog učešća u energetskoj stabilnosti i snabdevanju, RF ima u vidu da su okolne zemlje izuzetno bogate prirodnim sirovinama ili se nalaze na njihovom tranzitnom putu. U blizini se nalazi postojeći naftovod od Azerbejdžana, kao ključnog snabdevača Turske na liniji Baku-Tbilisi-Cejhan, i , Južnokavkaski” gasovod Baku-Tbilisi-Erzurum, kojim se preko Gruzije snabdeva Turska. Jedan od zapadnih projekata bio je i gasovod Nabuko koji je trebalo da dopremi gas u Evropu iz Iraka, Azerbejdžana, Turkmenistana i drugih zemalja bogatih gasom. Međutim, zbog širenja ratnih dejstava u regionu i nemo-

\footnotetext{
${ }^{23}$ Global Strategic Trends 2007 - 2036, The Developement, Concepts and Doctrine Centre (DCDC) - Ministry of Defence UK, jan. 2007, dostupno na: http://www.cuttingthroughthematrix.com/articles/strat_trends_23jan07.pdf, str. 33.

${ }^{24}$ Distribution of Fossil Fuels between Stock Exchanges - CTI map 2013, The Carbon Tracker initiative, 16.10.2013., dostupno na: http://www.carbontracker.org/in-the-media/distribution-of-fossil-fuels-between-stockexchanges-cti-map-2013.
} 
gućnosti da se obezbede snabdevači gasovoda, projekat je otkazan 2013. godine. Slična je i zamisao ,Južnog koridora” koji ima za cilj da iz sličnih izvora dovede gas do Evrope i delimično smanji ruski energetski uticaj na Evropu. Sve su to modeli (slika 2) koji posredno mogu smanjiti ruski uticaj na evropsku energetsku stabilnost.

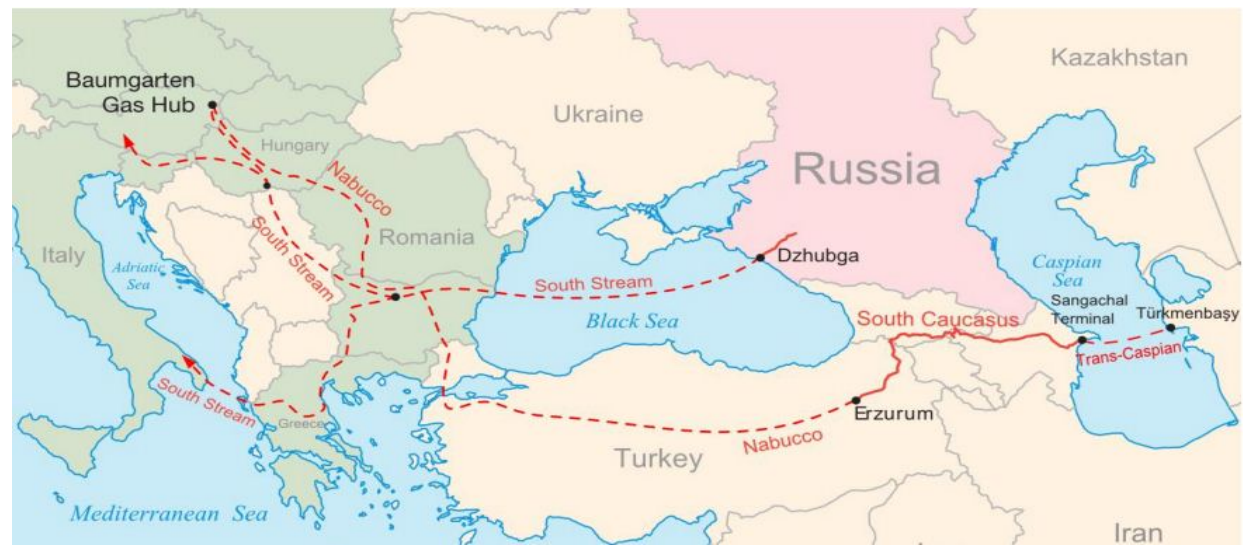

Slika 2 - Planirani gasovodi za snabdevanje jugoistočne Evrope ${ }^{25}$

Rusija ima ogromnu potencijalnu količinu zemljišta i resursa na Arktiku. Njena teritorija na Arktiku iznosi oko tri miliona kvadratnih kilometara, što je ekvivalent veličini Indije. Na Arktik otpada $90 \%$ njene proizvodnje gasa, kao i $80 \%$ istraženih rezervi. ${ }^{26}$ Pored toga, ona nastoji da uveća svoja prava na tu teritoriju i u tom smislu tretira Arktik kao istinsko proširenje svoje severne granice.

\section{Bezbednost kroz razvoj Ruske Federacije}

Nove okolnosti u XXI veku nametnule su potrebu za novim dokumentom koji će sveobuhvatno regulisati pitanja nacionalne bezbednosti, politike odbrane, ali i zaštititi ekonomski rast. S tim u vezi, maja 2009. godine usvojena je ,Strategija nacionalne bezbednosti Ruske Federacije do 2020. godine". ${ }^{27}$

Novi dokument opširnije i detaljnije govori o nacionalnim interesima. Naglašava se da se izgradnja globalne i regionalne stabilnosti ugrožava razmeštanjem elemenata globalnog sistema protivbalističke odbrane SAD u Evropi. ${ }^{28}$ Ruska Federacija preduzima različite ak-

\footnotetext{
${ }^{25}$ European Southern Gas Corridor Survey, Study by Michael LaBelle, Budapest, 2011, dostupno na: http://energyscee.com/wp-content/uploads/2011/04/Southern-Gas-Corridor-Survey-Final.pdf, str. 6.

${ }^{26}$ Bžežinski, Z., op. cit., str. 121.

${ }^{27}$ Strategiя nacionalınoŭ bezopasnosti Rossiǔskoŭ Federacii do 2020 goda, Prezident Rossii, 2009, dostupno na: https://rg.ru/2009/05/19/strategia-dok.html.

${ }^{28}$ Ibidem., tačka. 12.
} 
tivnosti radi odgovora na novonastalu situaciju kroz razvoj novih balističkih raketa koje će nadvladati buduću odbranu SAD, ali i usavršavanje svojih sistema protivbalističke zaštite. ${ }^{29}$

Navodi se da će posebna pažnja međunarodne politike biti skoncentrisana na ovladavanju izvorima energetskih resursa. ${ }^{30}$ Po prvi put se navodi da stanje nacionalne bezbednosti RF direktno zavisi ne samo od funkcionisanja sistema odbrane, nego i od ekonomskog potencijala zemlje. Gledišta ekonomskog razvoja, kao bitnog činioca nacionalne bezbednosti, bila su u RF od ranije prisutna, ali nisu bila tako jasno izražena. Naime, poznato je da je RF velikim delom usmeravala određene pravce svoje politike ka održanju ekonomskog rasta. Osim rasta izvoza energenata koji je doprinosio ekonomskom rastu, omogućavanje velikim multinacionalnim kompanijama da ulažu u Rusiju ranije se smatralo nezaobilaznim korakom u razvoju ekonomije. Izgradnja sistema nacionalne bezbednosti RF postiže se, osim razvojem ekonomije, osiguranjem državne i opšte bezbednosti, povećanjem kvaliteta života građana, razvojem nauke, tehnologije i obrazovanja, zdravstvenim sistemom, razvojem i zaštitom kulture i ekološkom politikom.

Po prvi put ova strategija govori čak i o kulturnim pretnjama Rusiji među kojima se ubrajaju pokušaji revidiranja ruske istorije. Rusija se sistematski izborila sa stranim finansijerima različitih kulturnih i državnih pretnji i zabranila ih. Sistemski se ulaže u razvoj porodičnih vrednosti, a sprečavaju promocije duhovnih vrednosti koje nisu u skladu sa tradicionalnim ruskim duhovnim i kulturnim vrednostima.

Strategija je planirana da se ostvaruje kroz stalni razvoj Rusije, njenu realizaciju kao konkurente države sa visokotehnološkom industrijom, savremenim odbrambenim potencijalom i dostojnim životnim standardom naroda.

Uvažavajući široki opseg smernica navedenih u SNB RF do 2020. godine, februara 2010. godine usvojena je Vojna doktrina RF koja se nadovezuje na Vojnu doktrinu 2000. godine, ali se fokusira na aktuelne spoljne pretnje ugrožavanju nacionalne bezbednosti. Specifično, Vojna doktrina dozvoljava upotrebu oružanih snaga van granice RF, ${ }^{31}$ što po nekim analitičarima daje težište na zaštitu ruskih građana u bivšim sovjetskim republikama. ${ }^{32}$ Kasnije 2014. godine to ovlašćenje će biti potvrđeno dozvolom predsedniku RF da upotrebi oružane snage radi zaštite ruskog življa i interesa u Ukrajini, ali i Siriji.

U sprovođenju spoljne politike usmerenje daje dokument pod nazivom „O merama za sprovođenje spoljne politike Ruske Federacije”, ${ }^{33}$ objavljen 2012. godine. Ruska Federa-

\footnotetext{
${ }^{29}$ Malo je poznato da je SSSR (nakon odustajanja razvoja sličnih sistema u SAD 70-ih godina HH veka) imao jedini zadejstvovani sistem protivbalističke zaštite (popularno en. Anti-Ballistic Missile - AVM System) raspoređen da brani Moskvu i centralni industrijski region. Rad na usavršavanju specifičnih raketa i radara za tu namenu tekao je neprekidno u SSSR-u od 1972. godine pa do današnjih dana u RF. Juna 2016. godine RF je uspepšno testirala novu raketu A-235 (Nudol ABM system) koja je namenjena prvenstveno da presreće balističke rakete i uništava neprijateljske satelite, pri čemu je sistem pravljen da sadjstvuje sa postojećim PVO sistemima S-400 i budućim S500. Razvoj ruskih antibalističkih raketa uvek je bio jedna od najvećih tajni ruske vojne industrije, čak mnogo veća od razvoja interkontinentalnih balističkih raketa sa nuklearnim bojevim glavama ili ruskih nuklearnih podmornica.

${ }^{30}$ Ibidem., tačka. 11.

${ }^{31}$ Voennaя doktrina Rossiǔskoŭ Federacii, Prezident Rossii, 2010, dostupno na: http://news.kremlin.ru/ref_notes/461, tačka 26.

${ }^{32}$ Nichol, J.: Russian Military Reform and Defense Policy- Report for Congress, USA Congressional Research Service, 24.08.2011, dostupno na: http://www.fas.org/sgp/crs/row/R42006.pdf, str. 4.

${ }^{33}$ O merah po realizacii vnešnepolitičeskogo kursa Rossiǔskoŭ Federacii, Prezident Rossii, 2012, dostupno na: http://www.scrf.gov.ru/security/international/document124/.
} 
cija u spoljnoj politici nudi saradnju, ali ni u jednom trenutku ne zanemaruje ideju uticaja. Taj uticaj može se raspoznati u energetskom sektoru, zahvaljujući, pre svega, ogromnim ruskim prirodnim bogatstvima koje RF izvozi. Na taj način RF vidno utiče na zemlje Evrope i Azije. Različiti pokušaji da se smanji energetska zavisnost Evrope od RF nisu uspeli, često i zbog onemogućavanja alternativnih rešenja. Na te alternative u snabdevanju gasom RF je uvek imala različit uticaj, a često ih je na različite načine onemogućavala, a sve radi održanja svoje monopolske pozicije u snabdevanju.

Sagledavajući zvanična strategijska dokumenta SAD, Rusija je svesna da se proklamuje premeštanje težišta angažovanja van Evrope, tj. ka azijsko-pacifičkoj regiji. Takođe, očigledno je da SAD žele da evropski NATO saveznici preuzmu aktivniju ulogu u bezbednosti Evrope, kako bi oni svoje snage mogli da angažuju na drugim područjima. Ruska Federacija shvata da bezbednosni sistem NATO, koji je u XX veku bio pod presudnim uticajem i fokusom SAD, sada ne može da reaguje u Evropi na isti način kao nekad, jer je došlo do velikih ekonomskih i energetskih povezivanja Zapada sa Rusijom i mnogo veće međuzavisnosti ekonomski razvijenih evropskih država i RF. Prepuštanje glavne bezbednosne uloge evropskim državama vodi do teškog dolaska do jedinstvenog stava NATO-a po pitanju Rusije.

Kombinovano sa smanjenjem američkog uticaja, pojačava se i širi ruski vojni i politički uticaj u Evropi, kao posledica afirmacije ruske moći. On se ispoljava težišno, kao stvaranje zone uticaja u okruženju, gde je RF poslednjih godina stavila do znanja da postoji prag približavanja NATO-u ispod kojeg neće ići. Rat u Gruziji 2008. godine i kriza u Ukrajini pokazali su čvrst stav Rusije po tom pitanju. Rusija će, u skladu sa svojom vojnom doktrinom, održati pritisak na spoljnim granicama, ali neće ,,dirati” EU - NATO zonu ukoliko oni ne dirnu prvo zonu uticaja Rusije, kao što je i do sada bio slučaj. Dokaz za to bio je i kratkotrajni rat u Gruziji, gde je RF intervenisala zbog ugroženih interesa u regionalnom okruženju i ,,bačene rukavice” od strane Zapada. Period koji je usledio nakon tog rata označava kraj učvršćivanja pozicije RF u regionalnom okruženju i postavljanje viših ciljeva koji će dovesti do afirmacije RF kao velike svetske sile. Na taj način RF je ideju uticaja stavila u sam centar svog spoljnopolitičkog i bezbednosnog koncepta.

\section{Ruska Federacija ponovo u grupi velikih sila}

Sjedinjene Države i NATO, u kojem one imaju vodeću ulogu, i dalje imaju vojnu i ekonomsku nadmoć u odnosu na bilo koju drugu zemlju ili grupu zemalja u svetu. Međutim, od završetka hladnog rata najpre postepeno, a zatim ubrzano, vrši se prenos ekonomske moći sa Zapada na Istok. Prenos ekonomske moći povlači prenos vojne i političke moći i konkretizovanja multipolarnosti u globalnom okruženju.

U periodu koji je nastupio, proklamovano premeštanje interesovanja SAD na azijskopacifički region nije praktično usledilo, već je fokus angažovanja Zapada, ipak vidno bio na ruskom, afričkom i bliskoistočnom okruženju. Agresivno nastupanje SAD i zapadnih saveznika u toku ,,arapskog proleća”, građanski ratovi i smene režima doveli su do nekontrolisanog haosa u severnoafričkim i bliskoistočnim državama, razbuktavanja terorizma i kasnije izbegličkog talasa. S druge strane, podrška ukrajinskim snagama u smeni vlasti dovela je do rata u Ukrajini. Mada je u početku RF relativno pasivno pristupala an- 
gažovanju zapadnih saveznika u borbama protiv legalnih vlasti u severnoj Africi, u trenucima kada se težište sukoba premestilo bliže, RF je počela svoje značajnije vojno-političko angažovanje. Upravo ti potezi koje je RF pravovremeno povukla vratili su je u vrh svetskih zbivanja i afirmisali u potpunosti kao veliku svetsku silu.

Uticaj RF u međunarodnim odnosima konstantno i nezaustavljivo raste, a po nekim procenama prestići će i SAD u dugoročnom periodu (slika 3).

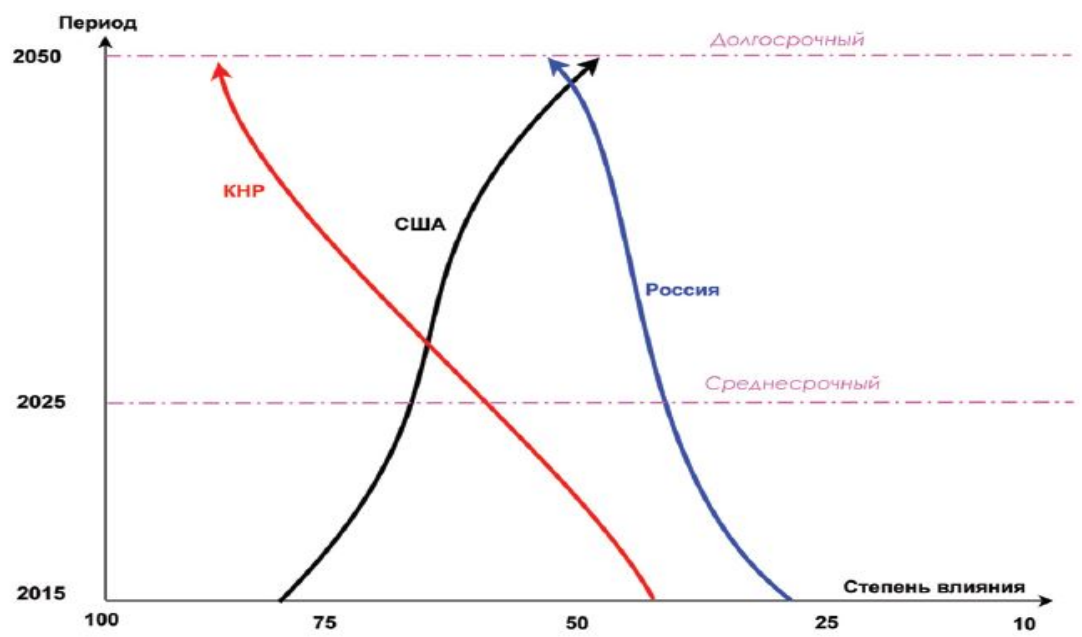

Slika 3 - Prognoza uticaja Kine, SAD i RF u međunarodnim odnosima u srednjoročnoj (2021-2025) i dugoročnoj perspektivi (2045-2050) ${ }^{34}$

Različiti geopolitički ciljevi RF i SAD, u poslednjih deset godina utiču, s jedne strane, na to da SAD štite unipolarni geopolitički poredak nastao devedesetih godina XX veka, a sa druge strane da RF izgrađuje svoj geopolitički blok i podstiče druge sile izvan Zapada, ali i na Zapadu, da izgrađuju multipolarni sistem međunarodnih odnosa. Jedan od načina na koji to radi je i učestvovanje u rešavanju bezbednosnih problema Bliskog istoka, ukrajinske krize, Balkana i Dalekog istoka. ${ }^{35}$ Upravo rezultat toga jeste da je između Rusije i SAD 2014. godine nastupilo najveće zahlađenje odnosa od završetka hladnog rata. ${ }^{36}$

Rusija počinje da definiše svoj geopolitički status na drugačijim osnovama nego što je to u zapadnoj geopolitici. Sebe prepoznaje kao zasebni geopolitički pol, koji ima dijalog sa Zapadom, kao i sa ostalim nezapadnim silama u nastajanju. Sagledavajući nove promene na svetskoj i lokalnoj sceni, RF objavljuje, na samom kraju 2015. godine, Strategiju nacio-

\footnotetext{
${ }^{34}$ Podberezkin, A. І.: Tretья mirovaя voŭna protiv rossii, Moskovskiй gosudarstvennый institut meždunarodnыh otnošeniй (MGIMO)- universitet MID Rossii, Moskva, 2015, str. 17.

${ }^{35}$ Kovač, M.: Interesi velikih sila na prostoru Balkana, Zbornik radova Naučni skup „,Srbija i strategijska raskršća" ISIKS-2016, septembar 2016, Beograd, 2016, str. 404.

${ }^{36}$ Perišić, S., Kajtez, M.: Savremeno geopolitičko sučeljavanje Rusije i Zapada - da li je na pomolu (novi) raskol između Evrope i Rusije?, Vojno delo, Medija centar ,,Odbrana”, 4/2015, Beograd, 2015, str. 56.
} 
nalne bezbednosti $\mathrm{RF}^{37}$ kojom ponavlja nerazdvojnost nacionalne bezbednosti i socioekonomskog razvoja. Ova strategija je usaglašena sa ranije objavljenom Vojnom doktrinom RF iz 2014. godine. ${ }^{38}$ Kasnije se, u toku 2016. godine, objavljuje i Koncept spoljne politike $\mathrm{RF}^{39}$ ali i drugi dokumenti koji u potpunosti zaokružuju strategijsko-doktrinarni sistem i stvaraju pretpostavke za dalju afirmaciju RF u međunarodnim odnosima.

Kao najveća pretnja prepoznaje se i ističe dalje približavanje NATO snaga ruskim granicama. Sjedinjene Države se ne zadržavaju na izgradnji protivraketnog štita, već pod plaštom ukrajinske krize pojačavaju i konvencionalne snage u okolini RF. Ruska Federacija nastavlja da preduzima različite mere kako bi parirala ovom približavanju snaga granicama, mada je svesna da bilo kakva trka u naoružanju nije ekonomski moguća. U tom smislu preduzima specifične mere koje su najvećim delom inicirane u ranijem periodu. Najvažnije od njih su razvoj sopstvenih modernih sredstava ratne tehnike koja mogu parirati zapadnoj tehnologiji, što je postignuto zadržavanjem naučne i proizvodne baze iz perioda SSSR-a. Istovremeno s tim dolazi do povećanja izvoza naoružanja i ekonomske dobiti. Ruska Federacija drži drugo mesto u internacionalnoj prodaji naoružanja sa $25 \%$ učešća u prodaji na svetskom nivou (prvo mesto zauzima SAD sa $33 \%$, dok je mnogo iza vodeće dvojke Kina sa 5,9\%, Francuska sa 5,6\% i Nemačka sa 4,7\%). ${ }^{40}$

U novoj SNB prepoznaje se dalje podrivanje snage Rusije koje je počelo još sa početkom njene revitalizacije. Kako RF ispoljava veći uticaj u svetskim poslovima, tako su primetni sve veći zapadni pritisci kako bi se ograničio rast uticaja Rusije. Nakon sukoba u Donbasu i obaranja malezijskog aviona iznad Ukrajine, koji su iskorišćeni kao povod, RF se isključuje iz Grupe osam najrazvijenijih industrijskih država (G-8), nameću joj se različite sankcije, obaraju se cene nafte, a sve s ciljem da se umanji snaga RF i posredno smanji njen uticaj u međunarodnim odnosima ${ }^{41}$ koji se na osnovama revitalizovane ekonomije ubrzano širio.

Odmereno angažovanje RF i čvrst odnos prema problemima u okruženju, ali pre svega izuzetno brzo reagovanje celog sistema nacionalne bezbednosti dovodi do situacije da je RF uvek korak ispred svojih protivnika. To je suštinski najuočljivija karakteristika ruskog delovanja ka međunarodnom okruženju. Kao što je 2008. godine u kratkom petodnevnom ratu brzom reakcijom nadvladana gruzijska vojska, tako je kasnije 2014. preuzeta kontrola nad Krimom, ali i započeto angažovanje u Siriji 2015. godine. Sve ove događaje karakterisala je nepredvidivost i potpuno iznenađenje zapadnih struktura moći koje su odavale utisak nemoći. Upravo takvi potezi vraćaju RF na svetsku političku scenu kao činioca sa kojim se mora razgovarati o svetskim pitanjima i bez kojih se svetski problemi ne mogu rešiti.

\footnotetext{
${ }^{37}$ Strategiя nacionalınoŭ bezopasnosti Rossiǔskoŭ Federacii, Prezident RF, 2015, dostupno na: http://www.scrf.gov.ru/security/docs/document133/.

${ }^{38}$ Voennaя doktrina Rossiǔskoŭ Federacii, Prezident RF, 2014, dostupno na: http://www.scrf.gov.ru/security/ military/document129/.

${ }^{39}$ Koncepciя vnešneŭ politiki Rossiǔskoŭ Federacii, Prezident RF, 2016, dostupno na: http://www.scrf.gov.ru/ security/international/document25/.

${ }^{40}$ SIPRY Yearbook 2016 - Armaments, Disarmament and International Security, Stockholm international peace research institute, Stockholm, 2016, str.19.

${ }^{41}$ Kovač, M., op. cit., str. 403.
} 
Primetna je uzlazna tendencija naglašavanja nacionalnih vrednosti RF koje se žele očuvati i unaprediti. Ne beži se od shvatanja da se poseduju materijalne vrednosti (neiscrpna bogatstva ogromnih teritorija), ali veliki značaj daje se i duhovnim vrednostima. Te vrednosti su posledica delom ruskog stvaralaštva kroz vekove, a delom posledica opštih civilizacijskih dostignuća. Upravo ta opšta civilizacijska dostignuća u Rusiji, radi rušenja njenog ugleda u globalnim okvirima, često osporavaju analize sa Zapada. Specifične duhovne vrednosti države u SNB RF se potenciraju kao velika snaga i opisuju kao zajednički ruski identitet naroda $i$ jedinstveni kulturni prostor zemlje. Strategija nacionalne bezbednosti naglašava njihovo postojanje i daje smernice za održanje i očuvanje svih nacionalnih vrednosti.

Karakteristika velikih svetskih sila svakako je delovanje specifičnim oblicima tvrde i meke moći na određene države. Neka od tih delovanja ispoljavaju se i kroz informacionu dimenziju. Evidentno je da se odnos javnog mnjenja na Zapadu polako okreće ka ruskom stavu. Veliki broj zemalja se stidljivo izjašnjava da su protiv daljeg produžavanja sankcija RF. Navedeno se posredno spoznaje kroz usvajanje rezolucije parlamenta EU za borbu protiv ,,pristrasnih" ruskih medija i njihovih „,dezinformacija”. ${ }^{42}$ Navedena rezolucija precizira načine suprotstavljanja ruskom informacionom uticaju u zemljama EU. Osim što je ona nastavak pritiska na RF od strane SAD i Zapada, predstavlja i posredno priznanje da ruski uticaj na Zapadu raste.

Na sličan način manifestuje se ruski uticaj na Balkanu. Skoro sve zemlje Balkana žele odnose na višem nivou sa RF i u manjoj ili većoj meri sarađuju sa njima. Specifičnosti odnosa RF i Srbije izraženi su kroz rusku međunarodnu podršku po pitanju nepriznavanja KiM i podršku Republici Srpskoj. Srbija se odužuje neuvođenjem sankcija RF i otvorenim i korektnim odnosom. Novi vojni aranžmani sa RF doprinose jačanju vojne i političke moći Republike Srbije. ${ }^{43}$ Prijateljstvo koje se unapređuje između dve države može postati ključno za rešavanje statusa KiM u bliskoj ili daljoj budućnosti. Odnos Rusije i Srbije razvija se na obostranu ekonomsku korist, a vodi razvijanju međudržavnih odnosa. Takav model RF nudi i drugim državama u okruženju, zalažući se za saradnju na ravnopravnim osnovama i uzajamnom uvažavanju.

Nova SNB RF potencira stanovište o izgradnji mehanizama regionalne bezbednosti i stabilnosti u azijsko-pacifičkom regionu na neblokovskim osnovama. Time se RF postavlja u položaj između Istoka i Zapada, ispoljava interesovanja za sve prostore i označava svoju prisutnost na svim delovima sveta. Jedan od najupečatljivijih geopolitičkih projekata RF jeste formiranje geopolitičkog bloka - Evroazijskog ekonomskog saveza, formiranog 2015. godine, koji se zasniva na jakom ekonomskom objedinjavanju zemalja bivšeg SSSR-a i drugih zemalja koje hoće da ostvare druge pogodnosti. ${ }^{4}$

U SNB iz 2009. godine kao nacionalni interes RF navodi se pretvaranje države ${ }^{45} u$ svetsku silu, dok se u SNB iz 2015. godine, pored ostalih nacionalnih interesa, pominje

\footnotetext{
${ }^{42}$ Strateška komunikacija EU u suprostavljanju propagandi, Rezolucija parlamenta EU, usvojena 23.11.2016., dostupno na: http://www.europarl.europa.eu/oeil/popups/ficheprocedure.do?lang=en\&reference= 2016/2030(INI).

${ }^{43}$ Tanjug, Kirov: Srbija postaje regionalni vojni faktor, dostupno na: http://www.tanjug.rs/full-view.aspx?izb=310890.

${ }^{44}$ Danas su članovi ovog saveza: Rusija, Belorusija, Jermenija, Kazahstan i Kirgizija. Za članstvo pregovaraju Egipat, Tajland, Iran, Mongolija i Srbija. Države kao što su Kina, Indija, Izrael i neke druge izrazile su interes za pristupanje u Savez. Pre izbijanja krize i Ukrajina je pozvana da postane deo saveza, ali se zbog kasnije spoljnopolitičke orijentacije to nije ostvarilo.

${ }^{45}$ Strategiя nacionalınoŭ bezopasnosti Rossiǔskoŭ Federacii do 2020 goda, 2009, tačka. 21.
} 
popravljanje statusa ${ }^{46}$ svetske sile u multipolarnom svetu. Na taj način RF konstatuje da je dostignut određeni nivo statusa. Rusija odbija da bude regionalna sila i odbacuje pritiske i usmeravanja koja je vode ka tome. Izjave Baraka Obame ${ }^{47}$ da je Rusija regionalna sila koja ugrožava samo svoje susede jer je slaba, govore o stavu koji treba nametnuti o Rusiji. Međutim, sa tim stavom nisu se složile ni evropske ni svetske političke garniture. ${ }^{48}$ Rusija svojim promišljenim i izuzetno odmerenim i pravovremenim političkim koracima uspeva da ubedi svetsko javno mnjenje u suprotno. Različitim vojno-političkim angažovanjem, kako u Ukrajini, tako kasnije i u Siriji, te stabilnim učešćem u rešavanju bitnih globalnih problema, RF se postavlja u sam vrh svetskog liderstva. Predsednički izbori u SAD 2016. godine dali su Rusiji mnogo veći značaj nego što se to dešavalo u prethodnim slučajevima. Debate o uticaju RF na ishod izbora stavljaju RF u sam vrh svetskih zbivanja i, na kraju, možda dovode i do njenog preuveličanog značaja.

\section{Zaključak}

Kriza globalne moći je kumulativni efekat dinamičkog pomeranja svetskog gravitacionog centra sa Zapada na Istok, ubrzanog izbijanja na površinu fenomena političkog buđenja, ali i slabih performansi Sjedinjenih Država na unutrašnjem i spoljašnjem planu od 1990. godine, kada su postale jedina supersila. lako su SAD još dominantne, kako ekonomski, tako i vojno, vidljivo je nastajanje nove i složene konstelacije moći u kojoj Azija ima sve veću ulogu. Uzdizanje RF i njena afirmacija kao velike sile donela je bitno drugačiju konstelaciju odnosa na međunarodnoj sceni. Preraspodela globalne moći uvek pojačava nestabilnost savremenih međunarodnih odnosa. Velike sile se nadmeću među sobom za resurse, bezbednost i ekonomski prestiž, čime se povećava potencijal za pogrešne kalkulacije i konflikte. U takvom okruženju RF se sve više geopolitički učvršćuje i jača. Koraci u tom pravcu išli su preko evroazijskog prostora, a u poslednje vreme i sve intenzivnije preko evropskog tla.

Put kojim se došlo do trenutnog statusa nije bio lak. Postignuto je jedinstvo ruskog nacionalnog bića, a fokus je na oživljavanju tradicionalnih i duhovnih vrednosti i religijskoj toleranciji. Rusija se u početku najvećim delom okrenula samoj sebi, odnosno unutrašnjem, prvenstveno ekonomskom razvoju. Nakon dostignutog nivoa ekonomske održivosti počelo je jačanje vojnih, političkih i drugih potencijala. Uporedo se širio i uticaj Rusije, kako u regionalnim, tako i u globalnim okvirima. Mnoge prepreke i ometanja ruskog napretka nisu dala rezultate već su, verovatno, samo ubrzale proces preraspodele globalne moći.

Rusija se nameće kao „,svetionik spasa” za narode i države koje su osetile negativne posledice zapadnih vrednosti. Predstavlja se kao država slobodnog sveta i postavlja sebe u poziciju kakva je nekad bila pozicija njihovih hladnoratovskih neprijatelja. Ekonomsko i vojno jačanje i borbeno angažovanje Ruske Federacije van njene teritorije uliva nadu nekim državama da će u određenim trenucima, ako budu na pravcu ruske politike, biti zaštićeni od negativnih zapadnih uticaja.

\footnotetext{
${ }^{46}$ Strategiя nacionalınoŭ bezopasnosti Rossiǔskoŭ Federacii, 2015, tačka. 21.

${ }^{47}$ Izjava data u posle Samita o nuklearnoj bezbednosti u Hagu, marta 2014. godine.

48 Žan Klod Junker, predsednik Evropske komisije, izjava data novembra 2016, https://www.rt.com/news/ 368363-juncker-russia-obama-error/.
} 
Može se reći da je proces afirmacije Rusije kao velike sile trajao od raspada SSSR-a, a završen je početkom njene nezaobilazne uloge u sirijskom konfliktu, ali i svim drugim globalnim dešavanjima. Ruska Federacija je u tom periodu prikazala mnogo veće domete svog uticaja u regionalnom i svetskom okruženju i time se postavila u potpunosti na visoko mesto koje zaslužuje u globalnim okvirima.

\section{Literatura}

[1] Bžežinski, Z.: Amerika-Kina i sudbina sveta, Albatros Plus, Beograd, 2013.

[2] Военная доктрина Российской федерации, Президент России, 2000, доступно на: http://www.ng.ru/politics/2000-04-22/5_doktrina.html. (07. novembar 2017)

[3] Военная доктрина Российской Федерации, Президент России, 2010, доступно на: http://news.kremlin.ru/ref_notes/461 (10. oktobar 2017)

[4] Военная доктрина Российской Федерации, Президент РФ, 2014, доступно на: http://www.scrf.gov.ru/security/military/document129/ (12. oktobar 2017)

[5] Global Strategic Trends 2007 - 2036, The Developement, Concepts and Doctrine Centre (DCDC) - Ministry of Defence UK, januar 2007, dostupno na:

http://www.cuttingthroughthematrix.com/articles/strat_trends_23jan07.pdf (05. oktobar 2017)

[6] Distribution of Fossil Fuels between Stock Exchanges - CTI map 2013, The Carbon Tracker initiative, 16.10.2013., dostupno na: http://www.carbontracker.org/in-themedia/distribution-of-fossil-fuels-between-stock-exchanges-cti-map-2013. (10. februar 2017)

[7] European Southern Gas Corridor Survey, Study by Michael LaBelle, Budapest, 2011, dostupno na: http://energyscee.com/wp-content/uploads/2011/04/Southern-Gas-Corridor-SurveyFinal.pdf. (04. novembar 2017)

[8] Kovač, M., Interesi velikih sila na prostoru Balkana, Zbornik radova Naučni skup „,Srbija i strategijska raskršća" ISIKS-2016, septembar 2016, Beograd, 2016.

[9] Концепция внешней политики Российской Федерации, Президент РФ, 2016, доступно на: http://www.scrf.gov.ru/security/international/document25/ (05. novembar 2017)

[10] Концепция национальной безопасности Российской Федерации, Президент России, objavljena 1997, dopunjena 2000, доступно на:

http://www.mid.ru/foreign_policy/official_documents/-lasset_publisher/CptlCkB6BZ29/ content/id/589768. (17. oktobar 2017)

[11] Lišanin, M., Cupać, B., Rusija, NATO, EU: Komplementarni ili konkurentski pogledi na novu bezbednosnu arhitekturu Evrope, Vojno delo, Medija centar „,Odbrana", proleće/2013, Beograd, 2013.

[12] Mirković, T., Strategije i ratne doktrine supersila i blokova, Medija centar „Odbrana”, Beograd, 2003.

[13] National Security Strategy of Engagement and Enlargement, The President of the United States, 1994, dostupno na: http://history.defense.gov/Portals/70/Documents/nss/ nss1994.pdf?ver=2014-06-25121219-500. (02. novembar 2017)

[14] Nichol, J.: Russian Military Reform and Defense Policy- Report for Congress, USA Congressional Research Service, 24.08.2011, dostupno na: http://www.fas.org/ sgp/crs/row/R42006.pdf. (14. oktobra 2017)

[15] О мерах по реализации внешнеполитического курса Российской Федерации, Президент России, 2012, доступно на: http://www.scrf.gov.ru/ security/international/document124/. (13. oktobra 2017)

[16] Perišić, S.: Nacionalna bezbednost kao jedan od osnovnih činilaca geopolitičkog pozicioniranja RF na početku XXI veka, Vojno delo, zima/2010, Beograd, 2010. 
[17] Perišić, S., Kajtez, M.: Savremeno geopolitičko sučeljavanje Rusije i Zapada - da li je na pomolu (novi) raskol između Evrope i Rusije?, Vojno delo, 4/2015, Beograd, 2015.

[18] Подберезкин, А. И., Третья мировая война против россии, Московский государственный институт международных отношений (МГИМО), университет МИД России, Москва, 2015.

[19] Sakan, M.: Geopolitika NR Kine, Vojno delo, jesen/2013, Beograd, 2013.

[20] SIPRY Yearbook 2016 - Armaments, Disarmament and International Security, Stockholm international peace research institute, Stockholm, 2016.

[21] Стратегия национальной безопасности Российской Федерации, Президент РФ, 2015, доступно на: http://www.scrf.gov.ru/security/docs/document133/ (25. oktobra 2017)

[22] Стратегия национальной безопасности Российской Федерации до 2020 года, Президент России, 2009, доступно на: https://rg.ru/2009/05/19/strategia-dok.html. (26. oktobra 2017)

[23] Strateška komunikacija EU u suprostavljanju propagandi, Rezolucija parlamenta EU, usvojena 23.11.2016., dostupno na:

http://www.europarl.europa.eu/oeil/popups/ficheprocedure.do?lang=en\&reference=2016/2030(INI). (02. novembra 2017)

[24] Tanjug, Kirov: Srbija postaje regionalni vojni faktor, dostupno na: http://www.vesti-online.com/Vesti/Svet/635531/Bugarski-general-Rusi-naoruzavaju-Srbe-a-namaNATO-nista (20. oktobra 2017)

[25] Todorović, M., Đorđević, S.: Multipolarna struktura međunarodnih odnosa na početku HHI veka, Vojno delo, 4/2015, Beograd, 2015. 